\title{
Basic wood density variations of Parkia velutina Benoist, a long-lived heliophilic Neotropical rainforest tree
}

\section{Hélène MOREL ${ }^{1}$ \\ Romain LeHNEBACH ${ }^{2,3}$ \\ Jérémy CIGNA ${ }^{1}$ \\ Julien RUELLE ${ }^{4}$ \\ Éric NICOLINI ${ }^{2,3}$ \\ Jacques BEAUCHÊNE ${ }^{1}$}

\section{${ }^{1}$ CIRAD}

UMR EcoFoG (AgrosParisTech, CIRAD, INRA, Université des Antilles,

Université de Guyane)

97387 Kourou

France

${ }^{2}$ CIRAD

UMR AMAP

34398 Montpellier

France

\section{${ }^{3}$ AMAP}

Univ Montpellier

CIRAD, CNRS, INRA, IRD Montpellier

France

${ }^{4}$ INRA

LERFoB

AgroParisTech

54000 Nancy

France

Auteur correspondant / Corresponding author: Hélène Morel - helene-morel@bbox.fr

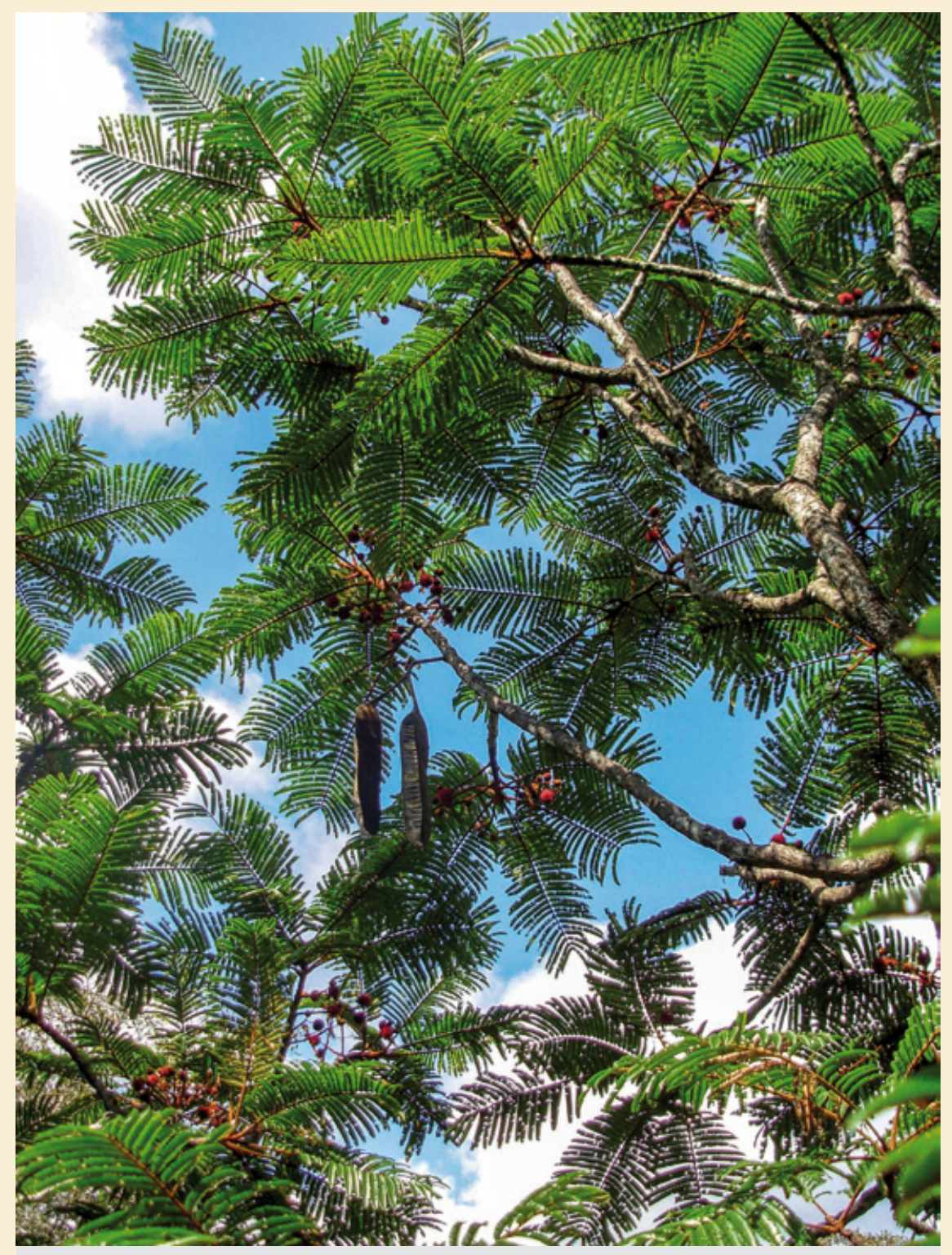

Photo 1.

Leaves, flowers and fruits of Parkia velutina.

Photo É. Nicolini.

\section{Ocirad (a)}

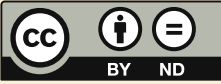

Licence Creative Commons :

Attribution - Pas de Modification 4.0 International.

Attribution-NoDerivatives 4.0 International (CC BY-ND 4.0)
Citer l'article / Cite the article

Morel H., Lehnebach R., Cigna J., Ruelle J., Nicolini E., Beauchêne J., 2018. Basic wood density variations of Parkia velutina Benoist, a long-lived

heliophilic Neotropical rainforest tree. Bois et Forêts des Tropiques, 335: 59-69. Doi: http://dx.doi.org/10.19182/bft2018.335.a31518 


\section{RÉSUMÉ}

\author{
Variations de la densité du bois \\ de Parkia velutina Benoist, essence \\ à longue durée de vie des forêts \\ humides néotropicales
}

L'analyse de la densité radiale des bois tropicaux révèle des profils linéaires et parfois curvilignes. Ce type d'étude ne prend généralement pas en compte les variations longitudinales, qui sont considérées comme similaires aux variations radiales. La présente étude vise à mettre en lumière (1) un nouveau profil curviligne de la densité radiale du bois, (2) des différences d'amplitude entre les gradients radiaux et longitudinaux et (3) à classer les variations de la densité du bois (DB) selon différentes échelles pour Parkia velutina, essence émergente des forêts humides néotropicales. La variabilité de la densité du bois a été évaluée sur des rondelles entières recueillies sur six arbres abattus et des carottes radiales prélevées sur dix arbres sur pied, et le taux de croissance en hauteur par des prélèvements sur un axe dominant. Cette essence montre des taux de croissance très élevés indicatifs d'un tempérament héliophile. La DB varie de 0,194 à $0,642 \mathrm{~g} / \mathrm{cm}^{3}$, amplitude rarement observée au sein d'un même arbre. La variation radiale de la DB est curviligne, l'amplitude radiale étant généralement plus faible qu'en longitudinal. En conséquence, pour les arbres matures, les valeurs DB dans les houppiers sont plus élevées que dans le tronc. Les variations de la DB peuvent être très significatives à différentes échelles. Le partitionnement de la variance montre également que l'estimation intra-individu de la DB pour l'essence Parkia velutina est plus précise si l'on prend en compte à la fois le gradient longitudinal et radial.

Mots-clés : profil curviligne, intra-arbre, essence tropicale, Guyane française.

\section{ABSTRACT}

\section{Basic wood density variations of Parkia velutina Benoist, a long-lived heliophilic Neotropical rainforest tree}

Investigations of basic radial wood density (WD) in tropical trees revealed linear patterns and some curvilinear patterns. Studies usually disregard longitudinal variations, which are often considered to be similar to radial variations. This study aimed to show (1) a new radial curvilinear WD pattern, (2) differences in amplitude between radial and longitudinal gradients and (3) to partition WD variations according to different scales in Parkia velutina, an emergent tree found in Neotropical rain forests. We collected full discs from six felled trees and radial cores from 10 standing trees to check WD variability, plus one dominant axis per tree for analysis of height growth rates. This species showed very high growth rates indicative of heliophilic habits. WD varied from 0.194 to $0.642 \mathrm{~g} / \mathrm{cm}^{3}$. Such amplitude is rarely observed within the same tree. Radial variation in WD was curvilinear, with an amplitude generally less than the longitudinal amplitude. Consequently, in mature trees, WD values in the crown were higher than those in the outer trunk. WD variations can be highly significant at different scales. The variance partitioning also revealed that the whole WD range of Parkia velutina is more accurately estimated intra-individually when both longitudinal and radial gradient are covered.

Keywords: curvilinear pattern, intra-tree, tropical species, French Guiana.

\section{RESUMEN}

\author{
Variaciones de la densidad básica de \\ madera de Parkia velutina Benoist, \\ especie longeva de las selvas \\ neotropicales
}

El análisis de la densidad radial básica de las maderas tropicales revela patrones lineales y, en ocasiones, curvilíneos. Los estudios no suelen integrar las variaciones longitudinales, consideradas como similares a las variaciones radiales. Este estudio tiene como objetivo poner de manifiesto (1) un nuevo patrón curvilíneo de la densidad radial de la madera, (2) las diferencias de amplitud entre los gradientes radiales y longitudinales y (3) clasificar las variaciones de la densidad de la madera (DM), según distintas escalas, de Parkia velutina, especie emergente de los bosques húmedos neotropicales. Se evaluó la variabilidad de la densidad de la madera en rodajas completas sacadas de seis árboles talados y de cilindros radiales extraídos de 10 árboles en pie; además, se calculó la tasa de crecimiento de la altura mediante muestreos a lo largo de un eje dominante. Esta especie muestra unas tasas de crecimiento muy altas, indicativas de su comportamiento heliófilo. La DM varía de 0,194 a 0,642 g/ $\mathrm{cm}^{3}$, una amplitud raramente observada dentro del mismo árbol La variación radial de la DM es curvilínea, la amplitud radial suele ser menor que la longitudinal. En consecuencia, en árboles maduros, los valores de DM en la copa son más altos que en el tronco. Las variaciones de la DM pueden ser muy significativas en diferentes escalas. La distribución de la varianza muestra asimismo que la estimación intraindividuo de todo el rango de la DM de Parkia velutina es más precisa si se tienen en cuenta tanto el gradiente longitudinal como el radial.

PALABRAS CLAVE: patrón curvilíneo, intra-árbol, especie tropical, Guayana Francesa. 


\section{Introduction}

Wood density is now considered as a major tree functional ecological trait because it includes the expression of the genome, the ecological temperament and the history of tree functioning. Among tropical trees, basic wood density (WD), defined as wood dry mass divided by fresh volume (Kollmann and Côté, 1968), varies between 0.1 to more than $1.2 \mathrm{~g} / \mathrm{cm}^{3}$ (Chave et al., 2009; Zanne et al., 2009). This huge variation between species is related to different stages of ecological succession. Heliophilic species have a much lower WD than sciaphilic species (Wiemann and Williamson, 1988; Nock et al., 2009). Although, variation in WD has been shown to be highest between species (Maniatis et al., 2011), both within species and within tree variation (especially in tropical emergent species) are substantial (Nock et al., 2009; Osazuwa-Peters et al., 2014; Plourde et al., 2015; Wassenberg et al., 2015). Indeed, our knowledge about within tree WD variations and its functional significance has increased significantly in recent decades.

Diameter at breast height (DBH), followed by WD are the best predictors of above-ground biomass (AGB) and of carbon sequestration by trees (Ketterings et al., 2001; Chave et al., 2009, 2014; Vieilledent et al., 2012; Zhang et al., 2012). Consequently, a better knowledge of radial and longitudinal variations in WD within the tree will enable to more accurate estimates of the carbon stored by a given ecosystem. This is particularly applicable in the case of tropical forests, which contain a high diversity of tree species (Whitmore, 1990) and represent the main stock of carbon (Lewis et al., 2009).

Reaching the canopy is challenging for an individual tree due to high stand density and strong competition for light. To face this challenge, trees have evolved different biomass allocation strategies that influence both the range and the way that WD varies radially (i.e. from pith to bark). At the lower end of the shade tolerance continuum, pioneers and more generally heliophilic species increase rapidly in height to reach the light as fast as possible. This rapid increase in height is enabled by the production of low WD (Woodcock and Shier, 2002). When the tree crown reaches the canopy, its environment changes and growth in height decreases in favour of the development of the crown, which, in turn, creates mechanical stresses due to the tree's increasing self-weight and/or wind forces (Woodcock and Shier, 2002). This change triggers the production of relatively higher WD in order to maintain mechanical stature (Wiemann and Williamson, 1988, 1989; Rueda and Williamson, 1992; Woodcock and Shier, 2002; Nock et al., 2009). Inversely, at the other end of the shade tolerance continuum, shade tolerant or sciaphilic species grow more slowly and initially produce denser, stiffer more resistant wood, which is interpreted as an adaptation to resist pests and the falling leaves/ branches of taller neighbouring trees (Woodcock and Shier, 2002; Muller-Landau, 2004).

WD can thus vary radially within tree (Wiemann and Williamson, 1988, 1989; Woodcock and Shier, 2002; Nock et al., 2009; Hietz et al., 2013). This radial variation, estimated as the slope of the regression of WD on the distance from the pith, is strongly correlated with tree age but not with tree size, suggesting an ontogenetic control of radial WD variation (Rueda and Williamson, 1992; De Castro et al., 1993; Nock et al., 2009; Williamson and Wiemann, 2010, 2011; Williamson et al., 2012). This assumption holds only for species with a linear pattern. However further studies illustrated substantial diversity in radial gradients: four main patterns of variation in radial WD are reported in the literature. Patterns showing a linear radial increase with low values near the pith and high density values near the bark (Panshin and De Zeeuw, 1980; Wiemann and Williamson, 1988; De Castro et al., 1993; Williamson and Wiemann, 2010; Osazuwa-Peters et al., 2014) are associated with early successional behaviour (Woodcock and Shier, 2002), whereas patterns showing a linear radial decrease with high values near the pith and lower density near the bark (Panshin and De Zeeuw, 1980) are associated with late successional behaviour (Woodcock and Shier, 2002). The two other WD radial patterns are nonlinear with a concave or convex pattern (Williamson et al., 2012; Osazuwa-Peters et al., 2014). However, any successional behaviour was seen to be associated with the last non-monotonic pattern. Still, one could think that this pattern characterizes a heliophilic strategy, as shown by Williamson et al. (2012) in Schizolobium parahyba a typical short-lived Neotropical pioneer species.

Most studies focused on radial variation in WD (Butterfield et al., 1993; Woodcock and Shier, 2002; Nock et al., 2009; Williamson and Wiemann, 2010, 2011; Williamson et al., 2012; Hietz et al., 2013; Schüller et al., 2013; Osazuwa-Peters et al., 2014), whereas little is known about longitudinal variation in WD (Rueda and Williamson, 1992; Wiemann and Williamson, 2014; Wassenberg et al., 2015), probably because longitudinal pattern of wood properties has generally been considered to be similar to radial pattern (Lachenbruch et al., 2011) due to the same physiological age of the cambium at tree base and at tree tip.

In this paper, we show the entire WD pattern of a long-lived heliophilic forest tree by answering the two following questions: (1) What do the radial and longitudinal variations in the WD of the trees look like? (2) What is the pattern of radial variation in WD?

We chose Parkia velutina Benoist (Leguminosae: Mimosoideae), an emergent forest tree widely but discontinuously distributed in the Brazilian and Peruvian Amazon, French Guiana, eastern Venezuela and in Colombia west of the Andes (Hopkins, 1986). Not used in French Guiana, big trees are peeling for veneer industry in Brazil, when the heart is healthy. This species usually has low values of WD (about $0.4 \mathrm{~g} / \mathrm{cm}^{3}$, Zanne et al., 2009), but is a long-lived heliophilic species, i.e. intermediate between pioneer and hemi-tolerant, making this emergent Neotropical forest species particularly attractive to investigate WD variations within a tree, with respect to tree architecture and ontogeny. 


\section{Material and methods}

\section{Study site and climatic typology}

The study was conducted at the Paracou experimental site in the lowland tropical rainforest of French Guiana ( $5^{\circ} 18^{\prime} \mathrm{N}, 52^{\circ} 55^{\prime} \mathrm{W}$ ) (Gourlet-Fleury et al., 2004). The site receives nearly two-thirds of the annual 3,041 $\mathrm{mm}$ of precipitation between mid-March and mid-June, and less than $50 \mathrm{~mm}$ per month in September and October. A daily mean temperature of $25.8^{\circ} \mathrm{C}$ is almost constant over the year. The experimental site is a stand of old growth forest dominated by Leguminoseae, Chrysobalanaceae, Lecythidaceae, Sapotaceae and Burseraceae (Sabatier and Prévost, 1989).

\section{Tree sampling and measurements}

Since we knew very little about $P$. velutina, we first measured the height, diameter, architectural stages of development, crown position in a population of 90 individual forest trees. Height was assessed using a laser meter (Haglöf Vertex Laser L400) and diameter was measured using a dendrometer placed higher than breast height (2-3 m) to avoid buttress effects. In addition, we assessed crown architecture suspected to significantly affect WD. Like many species, $P$. velutina reaches its mature stage through a reiterative process (Oldeman, 1974), which changes the tree's architecture through the duplication of the architectural unit. Three architectural stages of development (ASDs) were recorded (figure 1d): ASD1 trees with sequential branches borne by an orthotropic trunk, ASD2 trees with erect branches ("reiterated branches") forming the future fork at the top of the trunk and some sequential branches always present below the fork, and ASD3 trees with reiterated branches forming a hemispherical shaped crown, whereas sequential branches are no longer present. Among our 90 trees, we classified 42 ASD1, 19 ASD2 and 29 ASD3 trees.

Next, among the 90 trees, we selected 10: one ASD2 tree $\left(\mathrm{N}^{\circ} 4\right)$ and nine ASD3 trees $\left(\mathrm{N}^{\circ} 6,7,9,10,11,12,13,14\right.$ and $\mathrm{N}^{\circ} 15$ ) (table I). From each, we extracted one radial wood core above breast height (between 2 and $6 \mathrm{~m}$ from the base of the trunk) with a 5-mm diameter increment borer, while a climber collected one dominant branch in the crown.

In addition, to be sure of observing the entire range of WD variability, we felled three young trees (ASD1: $\mathrm{N}^{\circ} 1$ and $\mathrm{N}^{\circ} 2 ; \mathrm{ASD}^{2}: \mathrm{N}^{\circ} 3$ ) and two large adult trees (ASD3; $\mathrm{N}^{\circ} 5$ and $\mathrm{N}^{\circ} 8$, table I) among the 90 forest trees plus a third adult tree (ASD3; $\mathrm{N}^{\circ} 16$ growing in the open condition in a large logging gap created 23 years ago). It was not the biggest tree to avoid a hollow trunk $(40 \mathrm{~cm}<D<50 \mathrm{~cm}$, figure 1). For each of these six trees, three wood discs were collected between the base of the trunk and the top of the crown: above breast height (between 2 and $6 \mathrm{~m}$ from the base of the trunk), below the fork and in the crown. In the field, the discs and the radial wood cores were sealed in plastic bags and plastic tubes, respectively, to prevent drying, and then stored in the refrigerator until the measurements were made. 
Table I.

Description of 16 sampled trees for WD measurements. ASD: Architectural stages of development. CP: Crown position. Trees with an asterisk are felled trees.

\begin{tabular}{|l|l|l|l|l|}
\hline Tree & $\begin{array}{c}\text { Diameter } \\
(\mathbf{c m})\end{array}$ & $\begin{array}{c}\text { Height } \\
(\mathbf{m})\end{array}$ & ASD & CP \\
\hline $1^{\star}$ & 10 & 12.7 & 1 & 4 \\
\hline $2^{\star}$ & 11 & 13.5 & 1 & 3 \\
\hline $3^{\star}$ & 11 & 11.6 & 2 & 3 \\
\hline 4 & 14 & 21 & 2 & 3 \\
\hline $5^{\star}$ & 42 & 31 & 3 & 4 \\
\hline 6 & 43 & 32 & 3 & 4 \\
\hline 7 & 47 & 33 & 3 & 4 \\
\hline $8^{\star}$ & 50 & 31 & 3 & 5 \\
\hline 9 & 51 & 33 & 3 & 4 \\
\hline 10 & 58 & 38 & 3 & 4 \\
\hline 11 & 69 & 34.5 & 3 & 4 \\
\hline 12 & 72 & 35 & 3 & 4 \\
\hline 13 & 73 & 38 & 3 & 5 \\
\hline 14 & 76 & 36 & 3 & 4 \\
\hline 15 & 80 & 36 & 3 & 5 \\
\hline $16^{\star}$ & 52 & 26 & 3 & 5 \\
\hline & & & & \\
\hline
\end{tabular}

Measurements of basic wood density (WD)

A diametral sample (i.e. bark to bark through the pith) of $2 * 2 \mathrm{~cm}$ section was extracted from each wood disc taken from the six felled trees $\left(\mathrm{N}^{\circ} 1,2,3,5,8\right.$ and 16) and tangentially cut into $0.5 \mathrm{~cm}$ segments from bark to bark for the young trees ( $\mathrm{N}^{\circ} 1,2$ and 3$)$ and into $1.5 \mathrm{~cm}$ segments for the adult's trees $\left(N^{\circ} 5,8,16\right)$, in such way that ensured the pith was included in a single segment.

A $2 \mathrm{~cm}$ long outer segment (close to the bark) was taken from the core of each 10 additional trees $\left(N^{\circ} 4,6,7,9\right.$, $10,11,12,13,14$ and $\left.\mathrm{N}^{\circ} 15\right)$. In addition, for these 10 trees, complete wood discs ( $\sim \mathrm{cm}$ in diameter) were also collected from the higher part of dominant branches.

In all cases, the bark and the pith were discarded. Within $24 \mathrm{~h}$ of sampling, the green volume of each segment was determined using the water displacement method. The wood samples were oven-dried at $103{ }^{\circ} \mathrm{C}$ for $72 \mathrm{~h}$ before weighing on a $0.2 \mathrm{mg}$ precision SARTORIUS balance. The WD of each sample was calculated as the ratio of dry mass to green volume $\left(\mathrm{g} / \mathrm{cm}^{3}\right.$, Kollmann and Côté, 1968).

\section{Measurement of longitudinal growth rates}

As the height growth rate is indicative of the development stage of the tree (juvenile, adult mature and senescent), we investigated the height growth rate of the branches of each tree sampled. The limits of the growth units (GUs) making up the axes were located by recognizing morpho-anatomical markers that result from the rhythmic activity of the primary meristems, and which persist in the bark and pith for several years (Barthélémy and Caraglio, 2007). According to a study by Nicolini et al. (2012) on $P$. velutina, we retrospectively identified, for different axes per tree, the last successive GUs and measured their lengths.

\section{Statistical analysis}

We compared the basal diameter and height of the three different architectural stages (ASD1, ASD2 and ASD3) in 90 trees using a nonparametric Kruskal-Wallis test followed by Tukey's honest significant difference test if the Kruskal-Wallis test was significant. The same procedure was used to compare mean WDs among three heights (basal, under the fork and in the crown) within each felled tree $\left(N^{\circ} 1,2,3,5,8\right)$. Tree $N^{\circ} 16$ was excluded from this analysis because of its hollow trunk.

Because we wanted to study tree behaviour according to tree size, the trees were classified in three groups as a function of basal diameter and the mean length of the last annual GUs. The first group (1) was composed of four trees (ASD1 and ASD2: $\mathrm{N}^{\circ} 1,2,3$ and 4) whose basal diameter was $<20 \mathrm{~cm}$, and whose mean length of the last annual GUs was $68 \mathrm{~cm}$. The second group (2) was composed of five trees $\left(\mathrm{N}^{\circ} 5,6,7,8\right.$ and 9) whose basal diameter ranged between 40 and $55 \mathrm{~cm}$, and whose mean length of the last annual GUs was $25 \mathrm{~cm}$. The last group (3) was composed of the five largest trees $\left(\mathrm{N}^{\circ} 11,12,13,14\right.$ and 15$)$ whose basal diameter ranged between 65 and $85 \mathrm{~cm}$, and whose mean length of the last annual Gus was $7 \mathrm{~cm}$. Tree $\mathrm{N}^{\circ} 10$ was excluded since it clearly did not fit in any group. We compared the WD in the crowns and trunks of the three groups with a nonparametric Kruskal-Wallis test followed by Tukey's honest significant difference test if the Kruskal-Wallis test was significant.

We performed a variance component analysis in order to assess the contribution of WD variation among measurement radius, measurement heights and individuals. $A$ random effects model with three nested levels of random effects (individuals/height/radius) was used to estimate the proportion of variation in WD associated with individuals, height and radius. The residual variation included variation associated with segments plus measurement error.

Radial patterns of WD variations at different heights and in different individuals were modelled using multilevel linear mixed effect models (Pinheiro and Bates, 2000). As WD varies radially, we used distance from the pith as a fixed effect and selected three nested random factor levels that enabled modelling of WD at different scales: between and within individuals. These three nested random factors levels were (1) individual, (2) height within an individual and (3) sampled radius within height.

As a curvilinear pattern exists (Williamson et al., 2012; Osazuwa-Peters et al., 2014), we first specified a full multilevel mixed-effects quadratic model, for which all terms have random effects at all nested levels considered (table II). Let $W D_{i j k d}$ be the WD value of the $d^{\text {th }} 0.5 \mathrm{~cm}$ interval from the pith of the $k^{\text {th }}$ radius within the $j^{\text {th }}$ height within $i^{\text {th }}$ individual, our full species-level model is expressed as follow: 
$W D_{i j k d}=\left(\beta 0+\beta 0_{i}+\beta 0_{i j}+\beta 0_{i j k}\right)+\left(\beta 1+\beta 1_{i}+\beta 1_{i j}+\beta 1_{i j k}\right)^{*} x_{i j k d}+$ $\left(\beta 2+\beta 2_{i}+\beta 2_{i j}+\beta 2_{i j k}\right)^{*} x_{i j k d}{ }^{2}+\varepsilon_{i j k d}$

where $\mathrm{x}$ is the distance from the pith, and $\varepsilon_{\mathrm{ijkd}}$ is the within group error.

We also specified a full multilevel mixed-effects linear model:

$W D_{i j k d}=\left(\beta 0+\beta 0_{i}+\beta 0_{i j}+\beta 0_{i j k}\right)+\left(\beta 1+\beta 1_{i}+\beta 1_{i j}+\beta 1_{i j k}\right)^{\star} x_{i j k d}+\varepsilon_{i j k d}$

The most parsimonious model was selected using a series of reduced models that vary in their inclusion of random effects (table II). We derived both quadratic and linear models and computed the corrected Akaike information criterion (AICC) for each derived model. We selected the model with the lowest AICc.

All analyses were conducted in R version 3.2.2 ( $R$ Core Team, 2012) using the "base" (R Core Team, 2012) and "nlme" (Pinheiro et al., 2013) packages.

\section{Results}

\section{Allometry, architecture and longitudinal growth rates at the population scale}

The diameter and height of the measured trees ranged from 3 to $80 \mathrm{~cm}$ and from 3 to $38 \mathrm{~m}$, respectively (figure $1 \mathrm{a}$ ). The height/diameter relationship for $P$. velutina trees of Paracou was fitted by a linear model involving $\log (\mathrm{D})$ (figure $1 \mathrm{a}$, red line). In small trees ( $\mathrm{D}<25 \mathrm{~cm}$ ), height increased sharply with increasing diameter but slowed down in bigger trees
(D > $25 \mathrm{~cm}$ ). Height and diameter efficiently distinguished the different development stages of our samples. Only ASD1 trees were observed in the first part of the curve (D mean = $12.6 \pm 4.3 \mathrm{~cm}$ and $\mathrm{H}$ mean $=14.2 \pm 4.8 \mathrm{~m}$ ), whereas ASD3 trees were found only in the second part of the curve (D mean $=52.2 \pm 16.1 \mathrm{~cm}$ and $\mathrm{H}$ mean $=31.6 \pm 5.1 \mathrm{~m})$. ASD2 trees symbolized the transition between the two other stages ( $D$ mean $=21.5 \pm 7.3 \mathrm{~cm}$ and $\mathrm{H}$ mean $=22.5 \pm 6.5 \mathrm{~m}$ ). Although the different architectural stages overlapped a little, we observed significant differences in diameter (Kruskal-Wallis test; $p$-value $<0.001$ ) and in height (Kruskal-Wallis test; $\mathrm{p}$-value $<0.001$ ) in the ASD classes (figure 1b). On the basis of the mean length of the last annual GU as a function of tree diameter (figure 1c), we also distinguished three groups that differed significantly both in trunk diameter (Kruskal-Wallis test; p-value 20.001 ) and in the length of the last annual GU (Kruskal-Wallis test; $p$-value $<0.001)$. To sum up, trees with the biggest diameters had the shortest GU and conversely. So, we were able to distinguish two vigour groups among the ASD3 trees: young adult trees and pre-senescent adult trees.

\section{Contribution of WD variation among individuals, heights, and radius}

Variance component analysis depicted the contribution of the three nested factors (individual/height/radius) to the overall variation of WD (figure 2). Surprisingly, the measurement height within individuals contributes to the bulk

\begin{tabular}{|c|c|c|c|c|c|c|c|c|c|c|c|c|c|c|c|}
\hline \multirow[b]{4}{*}{ full } & \multicolumn{15}{|c|}{$\begin{array}{l}\text { Table II. } \\
\text { Description of the fitted linear mixed-effects models. The table presents the inclusion of both fixed and random } \\
\text { effects for each model }(\mathrm{X}) \text {. For each model, the number of freedom degrees as well as the corrected Akaike } \\
\text { Information criterion }(\mathrm{AIC}) \text { are presented. The } \triangle \mathrm{AICC} \text { is equal to the difference between the AICc of the model } \\
\text { and the lower AICc. }\end{array}$} \\
\hline & \multicolumn{3}{|c|}{ Fixed effects } & \multicolumn{3}{|c|}{ Individual } & \multicolumn{3}{|c|}{$\begin{array}{c}\text { Random effects } \\
\text { Height }\end{array}$} & \multicolumn{3}{|c|}{ Radius } & \multirow[t]{2}{*}{ df } & \multirow[t]{2}{*}{ AICc } & \multirow[t]{2}{*}{$\triangle \mathrm{AICC}$} \\
\hline & $\beta 0$ & $\beta 1$ & $\beta 2$ & $\mathrm{BO}_{\mathrm{i}}$ & $\beta 1_{i}$ & $\beta 2_{i}$ & $\beta 0_{i j}$ & $\beta 1_{i j}$ & $\beta 2_{i j}$ & $\beta 0_{i j k}$ & $\beta 1_{\mathrm{ijk}}$ & $\beta 2_{i j k}$ & & & \\
\hline & $x$ & $x$ & $x$ & $x$ & $x$ & $x$ & $x$ & $x$ & $x$ & $x$ & $x$ & $x$ & 13 & $-912,36$ & 1,9 \\
\hline $\mathrm{m} 1$ & $x$ & $x$ & $x$ & $x$ & $x$ & $x$ & $x$ & $x$ & $x$ & & $x$ & $x$ & 12 & $-912,45$ & 1,82 \\
\hline $\mathrm{m} 2$ & $x$ & $x$ & $x$ & $x$ & $x$ & $x$ & $x$ & $x$ & $x$ & & & & 10 & $-827,34$ & 86,92 \\
\hline m3 & $x$ & $x$ & $x$ & $x$ & $x$ & $x$ & & $x$ & $x$ & & $x$ & $x$ & 11 & $-734,42$ & 179,85 \\
\hline m4 & $x$ & $x$ & $x$ & & $x$ & $x$ & $x$ & $x$ & $x$ & & $x$ & $x$ & 11 & $-914,27$ & 0 \\
\hline $\mathrm{m} 5$ & $x$ & $x$ & $x$ & & & & $x$ & $x$ & $x$ & & $x$ & $x$ & 9 & $-710,77$ & 203,49 \\
\hline m6 & $x$ & $x$ & $x$ & & $x$ & $x$ & & & & & $x$ & $x$ & 8 & $-497,73$ & 416,53 \\
\hline fulls & $x$ & $x$ & & $x$ & $x$ & & $x$ & $x$ & & $x$ & $x$ & & 9 & $-862,97$ & 51,3 \\
\hline $\mathrm{m} 1 \mathrm{~s}$ & $x$ & $x$ & & $x$ & $x$ & & $x$ & $x$ & & & $x$ & & 8 & $-864,97$ & 49,3 \\
\hline $\mathrm{m} 2 \mathrm{~s}$ & $x$ & $x$ & & $x$ & $x$ & & $x$ & $x$ & & & & & 7 & $-812,88$ & 101,39 \\
\hline $\mathrm{m} 3 \mathrm{~s}$ & $x$ & $x$ & & $x$ & $x$ & & & $x$ & & & $x$ & & 7 & $-619,81$ & 294,46 \\
\hline $\mathrm{m} 4 \mathrm{~s}$ & $x$ & $x$ & & & $x$ & & $x$ & $x$ & & & $x$ & & 7 & $-866,97$ & 47,3 \\
\hline $\mathrm{m} 5 \mathrm{~s}$ & $x$ & $x$ & & & & & $x$ & $x$ & & & $x$ & & 6 & $-708,76$ & 205,51 \\
\hline $\mathrm{m} 6 \mathrm{~s}$ & $x$ & $x$ & & & $x$ & & & & & & $x$ & & 5 & $-490,18$ & 424,08 \\
\hline
\end{tabular}




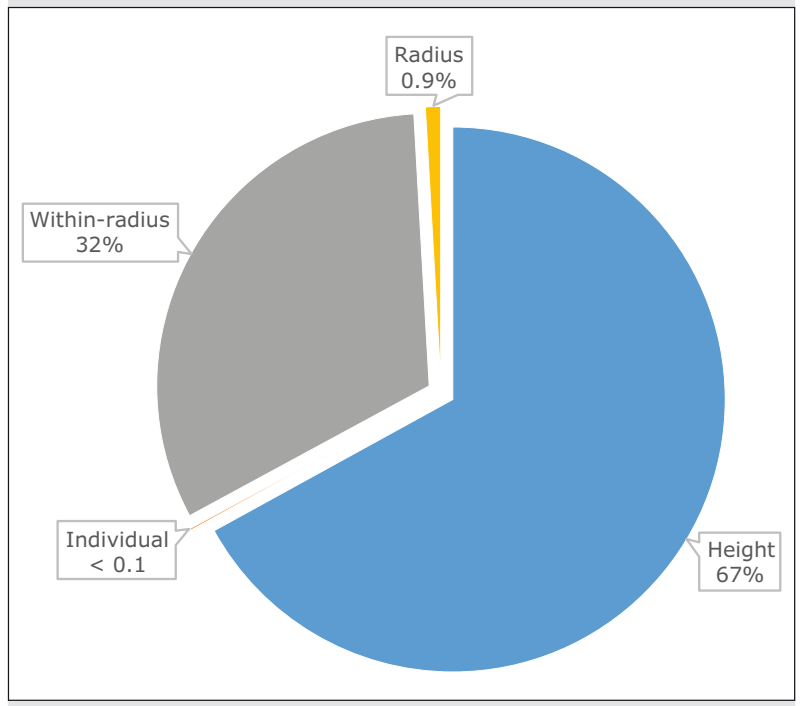

Figure 2.

Variance component analysis depicting the contribution of the three nested factors (individual/height/radius) to the overall variation of WD.

of the variation in WD (67\%). Variation among segments within radius is the second contributor to WD variations with $32 \%$. Finally, the variation attributed to the individual level and between radius within height are marginal, with $<1 \%$ and $<0.1 \%$ respectively. Height and among-segments levels being the most important, this variance partitioning analysis suggests strong longitudinal and radial variation in WD.

\section{Longitudinal variations in WD with ontogeny and within the sampled trees}

The outer WD at the base of the trunk increased gradually from group 1 to group 3 (figure 3), while the WD values in the crown top increased significantly from group 1 to group 2 but not from group 2 to group 3 (figure 3 ). Finally, the WD at the top of the crown was significantly higher than outer WD at the base of the trunk in both groups 2 and 3 (ASD3 trees), but not in group 1 (ASD1 and ASD2, figure 3).

In the six felled trees, WD ranged from 0.194 to $0.642 \mathrm{~g} /$ $\mathrm{cm}^{3}$ with an average of $0.392 \mathrm{~g} / \mathrm{cm}^{3}$, however the same range was also observed in a single tree (figure 4). Mean WD in the crown was higher than mean WD at the base of the trunk and under the fork. Above all, in three adult trees ( ${ }^{\circ} 5,8$ and 16), the WD under the fork was between WD at the base of the trunk and WD in the crown. A visual assessment was sufficient to state that the within disc variability in the crown was less than that in the trunk.

\section{Mixed-effects modelling of radial variations in WD}

The radial gradient in WD was best fitted by the quadratic regression model (figure 4). $\mathrm{AICC}$ is the lowest for the $\mathrm{m} 4$ model $(\mathrm{AICC}=$ -914.27, table II). This model includes random effect on both linear and quadratic terms for all levels considered. Nevertheless, it only includes random effect on intercept for height, suggesting that the WD at stem centre varies with measurement height. In counterpart, the absence of random effect on intercept for the individual level suggests that the mean WD along the stem centre does not varies between trees.

According to the mixed-effect modelling and the visual assessment of WD variations (figure 4), the lowest values of WD were observed in the inner wood at the base of the trunk whereas highest values were recorded in the crown.

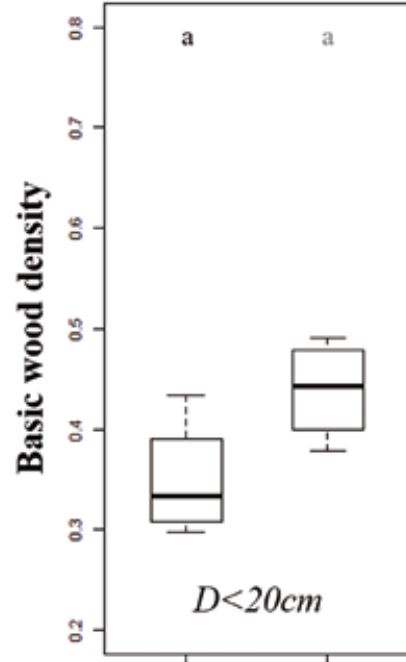

Base of the trunk Top
Base of the trunk Top
Figure 3.

Mean basic wood density (WD, in $\mathrm{g} / \mathrm{cm}^{3}$ ) at the base of the trunk and at the top of the crown from the $2 \mathrm{~cm}$ outermost segments of the three ontogeny groups (Group $1: n=4$, diameter $<20 \mathrm{~cm}$, Group 2: $\mathrm{n}=5$, diameter between 40-55 cm, Group 3: $n=5$, diameter between 65-85) of trees of Parkia velutina. For each group, a Kruskal-Wallis test was used to compare the two heights; the star indicates a significant difference $(P>0.05)$. For each height, a KruskalWallis test was used to compare the three groups; pairs with the same letter are not significantly different $(P>0.05)$. Kruskal-Wallis test was followed by post-hoc multiple comparison tests if the Kruskal-Wallis test was significant. 


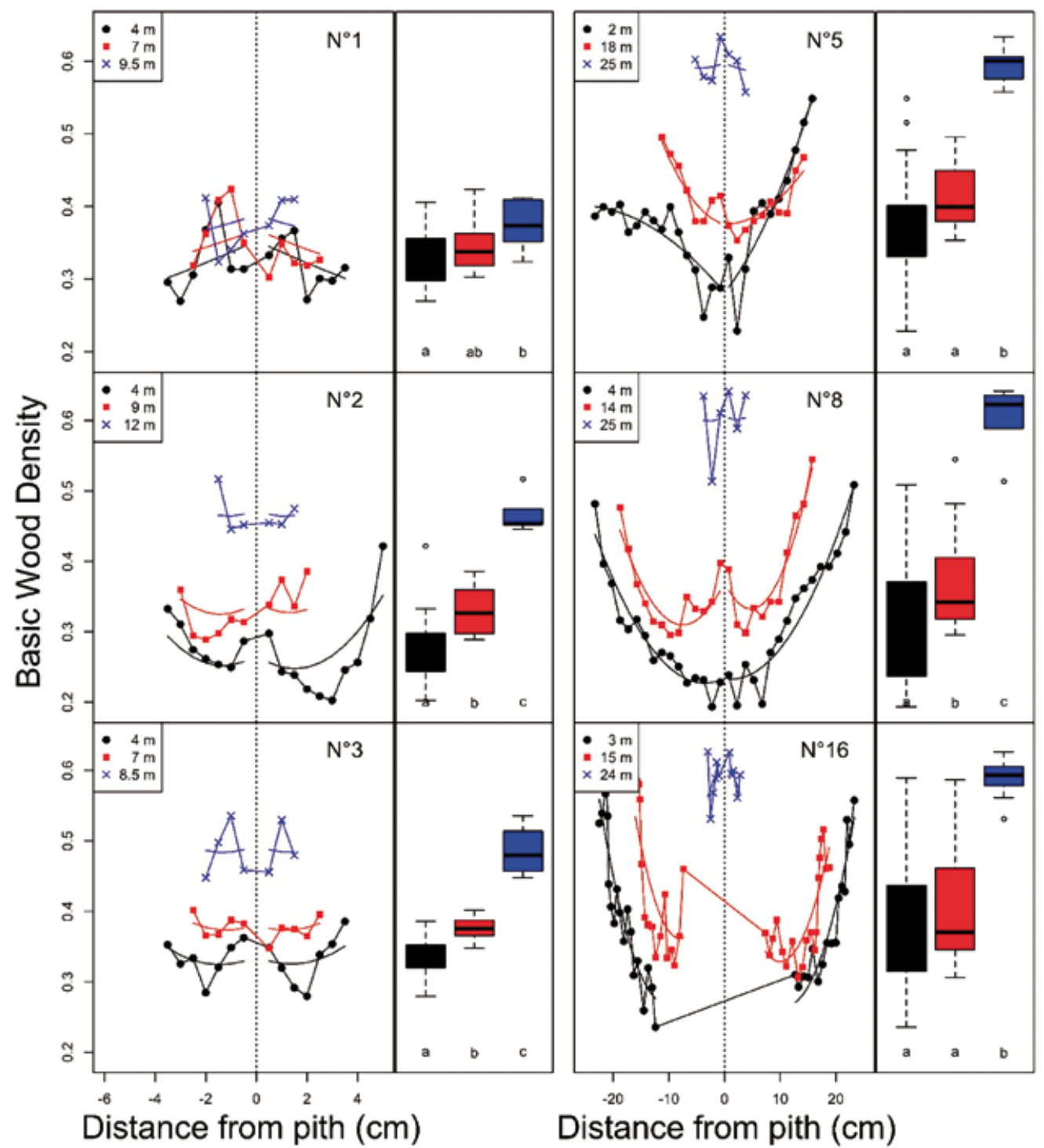

Figure 4.

Radial and longitudinal variation in basic wood density (WD, in $\mathrm{g} / \mathrm{cm}^{3}$ ) according to distance from the pith in six Parkia velutina trees ( $\mathrm{N}^{\circ} 1,2,3,5,8$ and 16). Mean basic wood density (WD) for the three heights (on the trunk (between 2 and $6 \mathrm{~m}$, in black), under the fork (in red) and in the crown (in blue) for the six felled trees. Kruskal-Wallis tests were used to compare the three groups within each individual; pairs with the same letter are not significantly different $(P>0.05)$. Kruskal-Wallis tests were followed by post-hoc multiple comparison tests if the Kruskal-Wallis test was significant.

\section{Discussion}

\section{Parkia velutina, a heliophilic long lived trees}

In our study, we combined a precise description and fine-scale measurement of WD variability according to the tree ontogenic development and architecture. These approaches allowed us to highlight the fact that growth rate varies considerably with tree diameter and height. These notable variations can be explained by the ecological temperament of $P$. velutina, which is between that of a strictly heliophilic species like Cecropia obtusa, for example, and a hemi-tolerant species like Dicorynia guianensis.

Like a pioneer species, $P$. velutina reaches the canopy as rapidly as possible, as reflected in the very long successive GUs (more than $150 \mathrm{~cm}$ ) observed in young trees (e.g. in ASD1) (figure 1). Rapid longitudinal growth is enabled by the production of wood with low inertia (low density) (figure 4) and high growth rate as previously reported in tropical pioneers (Williamson et al., 2012). When the tree reaches a sufficient height, and can intercept sufficient light, longitudinal growth starts to slow down in favour of crown expansion (i.e. the reiteration process, ASD2-3). At this time, the tree produces denser wood in the peripheral part of the trunk in order to maintain its mechanical stature (Fournier et al., 1991). Therefore, both the strong competition in height growth in the juvenile stages (heliophilic temperament) and the crown emergence/lateral expansion in the adult stages (long lived tree) may be the main factors that explain the strong radial range of WD encountered in this species. 


\section{A very wide range of wood density}

The very low initial values of WD $\left(0.2 \mathrm{~g} / \mathrm{cm}^{3}\right)$ also point to its heliophilic nature. This is one of the species with the lowest WD values recorded in French Guiana, since only balsa wood (Ochroma pyramidale) has a lower value $\left(0.13 \mathrm{~g} / \mathrm{cm}^{3}\right)$ (Rueda and Williamson, 1992). However, P. velutina also has a relatively high WD, i.e. around $0.64 \mathrm{~g} / \mathrm{cm}^{3}$, a value frequently encountered in middle successional forest species. In $P$. velutina, we thus found very high WD variability rarely reported in the literature except in Schizolobium parahyba (Williamson et al., 2012). On the other hand, such variations as we found in this species are not reported in the world wood density database (Zanne et al., 2009) which gives a WD value of about $0.40 \mathrm{~g} / \mathrm{cm}^{3}$ for $P$. velutina, whereas we found a very wide range of WD variability. This difference between studies is due to the fact that measurements are usually limited to the trunk, and, as a result the real variability of this pattern is probably not observed. In the present study on $P$. velutina, WD variability in the trunk (in the axes below the main fork supporting the crown) mainly ranged between 0.19 and $0.45 \mathrm{~g} / \mathrm{cm}^{3}$, whereas WD values inside the crown ranged from 0.45 to $0.64 \mathrm{~g} / \mathrm{cm}^{3}$. In studies that only consider certain parts of the tree, wide variability is usually not reported. In our opinion, WD amplitude may often be under-evaluated, since the crown has never previously been included in studies of the WD in this species.

\section{A significant difference between height at the base and top of the trunk}

In $P$. velutina, WD values in the crowns were significantly higher than values found in the trunks. Two possible explanations are that the canopy axes are (i) more exposed to wind, and (ii) more ramified than the trunk, as the foliage of each branch subject to strong windage. Stimulation of the branches by the wind may lead to the biosynthesis of stiffer and less fragile wood. In fact, like in Schizolobium parahyba (Williamson et al., 2012), in P. velutina, monopodial growth partially reduces the risk of stem collapse and bending or breakage. The difference in WD in the trunk and the crown observed in the big trees is more rarely observed in small trees. In fact, in our sample, the crowns of the three small trees were not dominant and not been exposed to wind, so an increase in the WD of the crown would not have been necessary. Conversely, tree $\mathrm{N}^{\circ} 16$ had grown in the open (emergent tree), and had to stiffen its structures by increasing its WD to stand up to the wind. This development resulted in a radial gradient mainly observed in the trunk of the trees and less in the crown. Contrary to the majority of previous studies in tropical pioneer species (De Castro, 1993; Williamson and Wiemann, 2010), this gradient was clearly non-linear in the trunk. Extreme radial increases in tropical trees were first reported in Ochroma pyramidale (Whitmore, 1973). Since then, the number of internationally published studies on radial variation in tropical trees has drastically increased and the total number of species studied is now about 100 (Wiemann and Williamson, 1988, 1989; Rueda and Williamson, 1992; Butterfield et al., 1993; De
Castro et al., 1993; Woodcock et al., 2000; Nock et al., 2009; Williamson and Wiemann, 2010, 2011), except Williamson et al. (2012) and Osazuwa-Peters et al. (2014) and the present study, few showed a curvilinear radial increase. In fact, tree growth is rarely symmetric around the trunk (Williamson and Wiemann, 2011). We observed differences in the pattern of radial variation between two radii within one tree. These differences are due to how the tree responds to local environmental conditions, the reorientation of the stems for better access to light often leads to eccentric growth and the production of tension wood (Pruyn et al., 2000).

\section{Variation of WD is essentially explained at the within tree level}

Whereas some results show that the bulk of WD variations is first explained at the inter-specific level followed by within-radius level and among-conspecific level (Osazuwa et al., 2014), our variance component analysis underlines a different pattern. We assume that this difference is afforded by the integration of samples from different height. As this study focused on a single species, our results are not directly comparable with studies involving several species but can be compared in a relative way. Osazuwa et al. (2014) found higher percentage of WD variance explained by the within-radius level than among conspecific level. Here, the longitudinal factor is such important in explaining WD variation that the within radius variation becomes secondary. We can first hypothesise that WD variation in $P$. velutina follows a particular pattern not generalizable to other species. However, Lehnebach (2015) showed the same trend in 16 Fabaceae species sampled at different heights, including $P$. velutina and other representatives of the same genus. More interestingly, as both longitudinal and radial variations explained almost all the variation of WD ( 99\%), the variance explained between individuals, although already weak in other studies (i.e. 4\% in Osazuwa et al. 2014), is negligible when accounting for variation with height. This observation provides interesting perspectives regarding the estimation of the whole range of WD covered by a species. Indeed, WD variations being essentially covered by the intratree level, the whole range of WD would be better estimated by replicating measurement at different positions within few individuals than estimating few WD values on a lot of individuals.

\section{Conclusion}

Variations in basic wood density (WD) were high at different scales: between sites, between ages, between trees and within individual trees. Our very selective sampling, based on the ontogenic development of the species, enabled us to access the expression of all this variability. Contrary to a local measure of WD, the complete pattern of WD provides satisfactory information on the temperament of the species. It also makes it possible to propose a model of the local density necessary for a better prediction of biomass / carbon models. 


\section{Acknowledgements}

This work was carried out within the framework of the DEGRAD project, with financial support from the European Regional Development Fund (FEDER). We are grateful to Onoefé Ngwete and Soepe Koese for helping us in the fieldwork and woodwork.

\section{Références bibliographiques}

Barthélémy D., Caraglio Y., 2007. Plant architecture: a dynamic, multilevel and comprehensive approach to plant form, structure and ontogeny. Annals of Botany, 99: 375-407.

Butterfield R. P., Crook R. P., Adams R., Morris R., 1993. Radial variation in wood specific gravity, fiber length and vessel area for two Central American hardwoods: Hyeronima alchorneoides and Vochysia guatemalensis: Natural and plantation-grown trees. IAWA Bulletin, 14: 153-161.

Chave J., Coomes D., Jansen S., Lewis L., Swenson N. G., Zanne A. E., 2009. Towards a worldwide wood economics spectrum. Ecology Letters, 12: 351-366.

De Castro F., Williamson G. B., Moraes de Jesus R., 1993. Radial variation in the wood specific gravity of Joannesia princeps: The role of age and diameter. Biotropica, 25: 176-182.

Fournier M., Chanson B., Thibaut B., Guitard D., 1991. Mécanique de l'arbre sur pied: modélisation d'une structure en croissance soumise à des chargements permanents et évolutifs. 2. Analyse tridimensionnelle des contraintes de maturation, cas du feuillu standard. Annals of Forest Science. 48 : 527-546.

Gourlet-Fleury S., Guehl J. M., Laroussinie O., 2004. Ecology and management of a neotropical rainforest - lessons drawn from Paracou, a long-term experimental research site in French Guiana. Elsevier, Paris, 326 p.

Hietz P., Valencia R., Wright S. J., 2013. Strong radial variation in wood density follows a uniform pattern in two neotropical rain forests. Functional Ecology, 27: 684-692.

Hopkins M. J., 1986. Parkia (Leguminosae: Mimosoideae). Monograph, Flora Neotropica 43, New York Botanical Garden, $124 \mathrm{p}$.

Ketterings Q. M., Coe R., van Noordwijk M., Ambagau Y., Palm C. A., 2001. Reducing uncertainty in the use of allometric biomass equations for predicting above-ground tree biomass in mixed secondary forests. Forest Ecology and Management, 146: 199-209.

Kollmann F. F. P., Côté W. A. Jr., 1968. Principles of Wood Science and Technology I: Solid Wood. Springer Verlag, Berlin.
Lachenbruch B., Moore J. R., Evans R., 2011. Radial variation in wood structure and function in woody plants, and hypotheses for its occurrence. In: Meinzer F. C., Lachenbruch B., Dawson T. E. (eds), Size- and age- related changes in tree structure and function. Springer, 121-164.

Lehnebach R., 2015. Variabilité ontogénique du profil ligneux chez les Légumineuses de Guyane Française. Thèse de Doctorat, Université de Montpellier, Montpellier, France.

Lewis S. L., Lopez-Gonzalez G., Sonké B., Affum-Baffoe K., Baker T. R., Ojo L. O., et al., 2009. Increasing carbon storage in intact African tropical forests. Nature, 457: 1003-1006.

Maniatis D., Saint André L., Temmerman M., Malhi Y., Beeckman H., 2011. The potential of using xylarium wood samples for wood density calculations: a comparison of approaches for volume measurement. iForest, 4: 150-159.

Muller-Landau H. C., 2004. Interspecific and inter-site variation in wood specific gravity of tropical trees. Biotropica, 36: 20-32.

Nicolini E., Beauchêne J., Leudet de la Vallée B., Ruelle J., Mangenet T., Heuret P., 2012. Dating branch growth units in a tropical tree using morphological and anatomical markers: the case of Parkia velutina Benoist (Mimosoideae). Annals of Forest Science, 69: 543-555.

Nock C. A., Geihofer D., Grabner M., Baker P. J., Bunyavejchewin S., Hietz P., 2009. Wood density and its radial variation in six canopy tree species differing in shade-tolerance in western Thailand. Annals of Botany, 104: 297-306.

Oldeman R. A. A., 1974. L'architecture de la forêt guyanaise. Mémoire $n^{\circ} 73$. ORSTOM, Paris, France.

Osazuwa-Peters O. L., Wright S. J., Zanne A. E., 2014. Radial variation in wood specific gravity of tropical tree species differing in growth-mortality strategies. American Journal of Botany, 101: 803-811.

Panshin A. J., De Zeeuw C., 1980. Textbook of wood technology. McGraw-Hill, New York, USA.

Pinheiro J., Bates D., 2000. Mixed-Effects Models in S and S-PLUS. Springer, New York. 
Pinheiro J., Bates D., Deb Roy S., Sarkar D., 2013. nlme: Linear and Nonlinear Mixed Effects Models. R package version 3.1-111 ed: $R$ package version 3.1-111.

Plourde B. T., Boukili V. K., Chazdon R. L., 2015. Radial changes in wood specific gravity of tropical trees: inter- and intraspecific variation during secondary succession. Functional Ecology, 29: 111-120.

Pruyn M. L., Ewers B. J., Telewski F. W., 2000. Thigmomorphogenesis: changes in the morphology and mechanical properties of two Populus hybrids in response to mechanical perturbation. Tree Physiology, 20: 535-540.

R Core Team, 2012. R: A language and environment for statistical computing. R Foundation for Statistical Computing, Vienna, Austria. http://www.R-project.org/

Rueda A. R., Williamson G. B., 1992. Radial and vertical wood specific gravity in Ochroma pyramidale (Cav. ex Lam.) Urb. (Bombacaceae). Biotropica, 24: 512-518.

Sabatier D., Prévost M. F., 1989. Quelques données sur la composition floristique et la diversité des peuplements forestiers de Guyane française. Bois et Forêts des Tropiques, 219: 31-55. http://revues.cirad.fr/index.php/BFT/article/ view/19645

Vieilledent G., Vaudry R., Andriamanohisoa S. F. D., Rakotonarivo O. S., Randrianasolo H. Z., Razafindrabe H. N., et al., 2012. A universal approach to estimate biomass and carbon stock in tropical forests using generic allometric models. Ecological Applications, 22: 572-83.

Wassenberg M., Chiu H.-S., Guo W., Spiecker H., 2015. Analysis of wood density profiles of tree stems: incorporating vertical variations to optimize wood sampling strategies for density and biomass estimations. Trees-Structure and Function, 29: 51-561.

Whitmore J. L., 1973. Wood density variation in Costa Rican balsa. Wood Science, 5: 223-229.

Whitmore T. C., 1990. An introduction to tropical rain forests. Clarendon Press, Oxford, UK, 548 p.

Wiemann M. C., Williamson G. B., 1988. Extreme radial changes in wood specific gravity in some tropical pioneers. Wood and Fiber Science, 20: 344-349.
Wiemann M. C., Williamson G. B., 1989. Wood specific gravity gradients in tropical dry and montane rain forest trees. American Journal of Botany, 76: 924-928.

Wiemann M. C., Williamson G. B., 2014. Wood specific gravity variation with heights, and its implications for biomass estimation. USDA Forest Service, Forest Products Laboratory, FPL-RP-677, 12 p.

Williamson G. B., Wiemann M. C., 2010. Age-Dependent Radial Increases in Wood Specific Gravity of Tropical Pioneers in Costa Rica. Biotropica, 42: 590-597.

Williamson G. B., Wiemann M. C., 2011. Age versus size determination of radial variation in wood specific gravity: lessons from eccentrics. Trees-Structure and Function, 25: 585-591.

Williamson G. B., Wiemann M. C., Geaghan J. P., 2012. Radial wood allocation in Schizolobium parahyba. American Journal of Botany, 99: 1010-1019.

Woodcock D. W., Dos Santos G., Taylor D., 2000. The buttressed blue marble tree: Wood and growth characteristics of Elaeocarpus angustifolius (Elaeocarpaceae). Annals of Botany, 85: 1-6.

Woodcock D. W., Shier A. D., 2002. Wood specific gravity and its radial variations: the many ways to make a tree. Trees-Structure and Function, 16: 437-443.

Zanne A. E., Lopez-Gonzalez G., Coomes D. A., Ilic J., Jansen S., Lewis S. L., et al., 2009. Global wood density database, Dryad. http://hdl.handle.net/10255/dryad.235

Zhang L. Y., Deng X. W., Lei X. D., Xiang W. H., Peng C. H., Lei P. F., et al., 2012 Determining stem biomass of Pinus massoniana $\mathrm{L}$. through variations in basic density. Forestry, 85: 601-60.

Bois et Forêts des Tropiques - Revue scientifique du Cirad
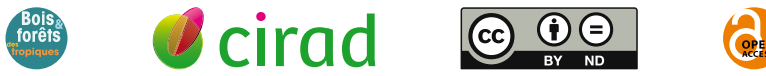

Cirad - Campus international de Baillarguet, 34398 Montpellier Cedex 5, France - Contact : bft@cirad.fr - ISSN : L-0006-579X 